\title{
A new rhabdovirus isolated in Japan from cultured hirame (Japanese flounder) Paralichthys olivaceus and ayu Plecoglossus altivelis
}

\author{
T. Kimura ${ }^{1}$, M. Yoshimizu ${ }^{1} \&$ S. Gorie ${ }^{2}$ \\ ${ }^{1}$ Laboratory of Microbiology, Faculty of Fisheries, Hokkaido University, Minato, Hakodate 041 , Japan \\ ${ }^{2}$ Hyogo Prefectural Fisheries Experimental Station, Akashi, Hyogo 673, Japan
}

\begin{abstract}
In March 1984, a new rhabdovirus was isolated from moribund cultured hirame (Japanese flounder) Paralichthys olivaceus and from ayu Plecoglossus altivelis fry in Hyogo Prefecture, Japan. From February through May 1985, the virus was again isolated from hirame in seawater tanks in Hyogo and Kagawa Prefecture, and in Hokkaido, Japan. At temperatures between 5 and $20^{\circ} \mathrm{C}$ the virus replicated and induced cytopathic effects (CPE), which progressed to eventual cytolysis, in susceptible cell lines, including FHM, EPC, BF-2, RTG-2, STE-137, HF-1, BB, YNK, CCO, and EK-1. The CHSE$214, \mathrm{KO}-6$ and $\mathrm{CHH}-1$ cell lines were refractory. Maximum virus titers of about $10^{9}$ to $10^{9.8} \mathrm{TCID}_{50} \mathrm{ml}^{-1}$ were obtained in FHM or EPC cell lines, and virus replicated optimally at 15 to $20^{\circ} \mathrm{C}$. Virus particles were bullet-shaped and measured $80 \mathrm{~nm} \times 180$ to $200 \mathrm{~nm}$. The isolate was sensitive to $\mathrm{pH} 3$, to diethyl ether, and to heat $\left(50^{\circ} \mathrm{C}, 2 \mathrm{~min}\right)$. Virus did not hemagglutinate human $\mathrm{O}$ type erythrocytes. Viral replication was not inhibited by $10^{-4} \mathrm{M}$ 5-iododeoxyuridine. Infectivity was not reduced by antisera aginst infectious hematopoietic necrosis virus (IHNV), viral hemorrhagic septicemia virus (VHSV), spring viremia of carp virus (SVCV), pike fry rhabdovirus (PFRV), eel virus-America (EVA), and eel virus-European (EVX). The viral isolate was pathogenic for rainbow trout Salmo gairdneri by injection but not for chum salmon Oncorhynchus keta, coho salmon $O$. kisutch, masu salmon $O$. masou, or ayu fry by water-borne exposure. The new virus has been named Rhabdovirus olivaceus (hirame rhabdovirus, HRV).
\end{abstract}

\section{INTRODUCTION}

An unknown disease occurred during March 1984 in cultured hirame (Japanese flounder) Paralichthys olivaceus held in pens in Fukura Bay, and in cultured ayu Plecoglossus altivelis fry held in seawater tanks at the Hyogo Prefectural Fisheries Experimental Station, Hyogo Prefecture, Japan (Gorie et al. 1985a, b). Common gross signs of the disease in hirame were congestion of the gonads, focal hemorrhage of the skeletal muscle and fins and accumulation of ascitic fluid; characteristic microscopic signs were pyknosis and necrosis of the hematopoietic tissue (Kimura et al. unpubl. data). Infected ayu fry exhibited exophthalmia and pethechiae on the opercula. The following year, in February to May 1985, the disease was again observed among the hirame cultured in seawater tanks at the Hyogo Prefectural Fisheries Experimental Station,
Negi Island, Kagawa Prefecture, and at Yagishiri Island, Hokkaido. Examination of diseased fish failed to show any bacterial, fungal or parasitic agents known to infect these hosts.

During the course of viral examination, infectious hematopoietic necrosis virus (IHNV)-like cytopathic effects (CPE) were observed in the RTG-2 cell cultures. The responsible agent was not neutralized with antisera prepared against known fish rhabdoviruses: IHNV, viral hemorrhagic septicemia virus (VHSV), spring viremia of carp virus (SVCV), pike fry rhabdovirus (PFRV), eel virus-America (EVA) and eel virusEurope (EVX). Pathogenicity and virulence of the isolate to the hirame was demonstrated by intraperitoneal injection (Gorie et al. 1985a).

In this report we describe the characteristics and pathogenicity of this new virus, named Rhabdovirus olivaceus or hirame rhabdovirus (HRV). 


\section{MATERIALS AND METHODS}

Viruses. Five isolates of HRV were used for virologi$\mathrm{cal}$ and serological studies. The HRV-8401H isolate originated from diseased hirame and the HRV-A $8401 \mathrm{H}$ isolate was cultured from moribund ayu fry at Hyogo Prefecture in March 1984 (Gorie et al. 1985a, b). The HRV-8501H, $8501 \mathrm{~K}$ and $8501 \mathrm{Y}$ isolates were obtained from diseased hirame in Hyogo Prefecture in February, Kagawa Prefecture in March, and Hokkaido in April 1985, respectively. The fish rhabdoviruses, SVCV, PFRV, EVA and EVX, and IHNV (strains IHNV$\mathrm{H}, \mathrm{ChAb}, \mathrm{HV}-1)$ were used as reference viruses. Two of the IHNV strains (ChAb and $\mathrm{HV}$-1) were stock viruses in our laboratory. The IHNV-H, SVCV, EVA and EVX were provided by Dr. B. J. Hill, Fish Diseases Laboratory, Ministry of Agriculture, Fisheries and Food, U. K., and PFRV was provided by Dr. P. de Kinkelin, Institut National de la Research Agronomique, France. Stock strains of infectious pancreatic necrosis virus (IPNV, serotype VR-299, Ab, and Sp) and Oncorhynchus masou virus (OMV, 00-7812) were also used as reference viruses.

Cell lines. The rainbow trout gonad cell line (RTG-2: Wolf \& Quimby 1962) was used for primary isolation and for routine propagation of the virus. The cell lines of fathead minnow (FHM: Gravell \& Malsburger 1965), epithelioma papilosum cyprini (EPC: Tomasec \& Fijan 1971), blue gill fry (BF-2: Wolf \& Quimby 1966), steelhead trout embryo (STE-137: Lannan et al. 1984), yamabe kidney (YNK: Watanabe et al. 1978), brown bullhead (BB: Wolf \& Quimby 1966), channel catfish ovary (CCO: Bowser \& Plumb 1980), eel kidney (EK-1: Chen et al. 1982), chinook salmon embryo (CHSE-214: Lannan et al. 1984), chum salmon heart (CHH-1: Lannan et al. 1984), kokanee salmon ovary (KO-6: Lannan et al. 1984) and hirame fin (HF-1: Yoshimizu \& Kimura unpubl.) were used for virus susceptibility tests. All cells were grown in Eagle's minimum essential medium prepared with Earle's salts (MEM; Gibco, Grand Island, New York, USA) and supplemented with $10 \%$ fetal bovine serum (FBS; Flow Laboratories, McLean, Virginia, USA) and antibiotics (100 I. U. penicillin $\mathrm{ml}^{-1} ; 100 \mu \mathrm{g}$ streptomycin $\mathrm{ml}^{-1}$ ). Except where noted, cells and virus were incubated at $15^{\circ} \mathrm{C}$.

Antisera. Antiserum aginst IHNV (HV-1) was provided by the Ministry of Agriculture and Fisheries, Japan, and antisera against IHNV-H, SVCV, EVA and EVX were provided by Dr. B. J. Hill $150 \%$ plaque neutralization titers of these sera were 13000,30000 , 600000 and 680000 , respectively). Anti-PFRV and polyvalent anti-VHSV sera were provided by Dr. P. de Kinkelin $150 \%$ plaque neutralization titers were 4000 and greater than 6400, respectively). Anti-VHSV serum was also provided by Dr. W. Ahne, Institut fur
Zoologie und Hydrobiologie, Universität München, F. R. Germany $(\log 10 \mathrm{NI}=3.0$ at $1: 100)$. Anti-IPNV (VR 299, Ab, and Sp) and anti-OMV sera were prepared in this laboratory ( $50 \%$ neutralization titers were 42000 , 3500,14000 , and 80 respectively).

Virus assay. The concentrations of infectious virus in characterization and neutralization studies were measured by $\mathrm{TCID}_{50}$ assay using RTG- 2 cells incubated at $15{ }^{\circ} \mathrm{C}$ for $7 \mathrm{~d}$. The titer was determined using 96 -well microplates (Flow Laboratories) and the endpoints were calculated by the method of Reed \& Muench (1938).

Ether sensitivity. One $\mathrm{ml}$ of diethyl ether was added to $4 \mathrm{ml}$ of clarified supernatant from an infected cell culture. This mixture and a control tube containing Hanks' balanced salt solution (BBS) in place of the ether were allowed to stand at $4{ }^{\circ} \mathrm{C}$ for $18 \mathrm{~h}$. The ether was then removed using nitrogen gas and the virus in the aqueous phase and the BBS contro! was titrated.

Resistance to 5-iododeoxyuridine (IUdR). Monolayer cultures of RTG- 2 cells were exposed to $10^{-4} \mathrm{M}$ IUdR (test cultures) or to BSS (control cultures). The test and control cultures were infected with virus, incubated at $15^{\circ} \mathrm{C}$ for $10 \mathrm{~d}$, and the virus was then titrated.

Stability to $\mathrm{pH}$ 3. Stability of $\mathrm{HRV}$ to $\mathrm{pH} 3$ was tested by incubating a suspension of virus in MEM adjusted to this $\mathrm{pH}$. Controls consisted of the virus suspended in MEM at $\mathrm{pH}$ 7.2. After $3 \mathrm{~h}$ incubation at $15^{\circ} \mathrm{C}$, the virus was titrated.

Hemagglutination with human Type O erythrocytes. The potential of HRV to hemagglutinate human Type $\mathrm{O}$ erythrocytes $\left(0.5 \%\right.$ suspension) at $\mathrm{pH} 7.2$ and $20^{\circ} \mathrm{C}$ was assessed using a standard microassay procedure commonly employed in mammalian virology (Hsiung 1982).

Heat inactivation. The virus suspension was distributed in $0.5 \mathrm{ml}$ aliquots into Kahn tubes which were placed in a 50 or $60^{\circ} \mathrm{C}$ water bath. At specified times thereafter samples were removed, rapidly cooled, and the remaining infectious virus was titrated.

Serological characterization tests. Neutralization of viral infectivity by antisera against HRV, IHNV, IPNV, VHSV, SVCV, EVA, EVX, PFRV, and OMV was tested by making serial 10 -fold dilutions in BSS of the supernatant from HRV-infected or reference virus-infected cultures and reacting $0.2 \mathrm{ml}$ of each dilution with $0.2 \mathrm{ml}$ of normal rabbit serum (1:100 in BSS) or rabbit antisera (HRV; IHNV; IPNV [VR-299, Ab, Sp]; SVCV; EVA and EVX, 1:100; IHNV [HV-1], 1:90; PFRV, 1:80; and $\mathrm{OMV}, 1: 20$ ). After incubation for $60 \mathrm{~min}$ at $15^{\circ} \mathrm{C}$, replicate portions $(0.1 \mathrm{ml})$ of each mixture were removed and assayed in FHM cells for detectable CPE.

The serological relations between HRV and the reference rhabdoviruses were determined by crossneutralization tests using rabbit antisera. Antisera 
were diluted with BSS at pH 7.2 in either 2 or 3 -fold steps. Each virus was harvested and diluted with BSS to give approximately $100 \mathrm{TCID}_{50} 0.05 \mathrm{ml}^{-1}$. Aliquots $(0.05 \mathrm{ml})$ of the virus suspension were reacted with 0.05 $\mathrm{ml}$ of each antiserum dilution at $15^{\circ} \mathrm{C}$ for $1 \mathrm{~h}$ following which a $0.1 \mathrm{ml}$ volume of FHM cells $\left(2.0 \times 10^{4}\right.$ cells 0.1 $\mathrm{ml}^{-1}$ ) was added to each reaction mixture. The resulting cultures were incubated at $15^{\circ} \mathrm{C}$ for $10 \mathrm{~d}$ and then observed for CPE. Neutralizing antibody titers were expressed as the reciprocal of the highest dilution of antiserum protecting $50 \%$ of the inoculated cell cultures.

Cell line susceptibility and virus replication. Monolayer cultures of FHM, EPC, BF-2, STE-137, RTG-2, HF-1, CCO, YNK, EK-1, CHSE-214, CHH-1, and KO-6 cells were prepared in 96-well plates. Stock cultures of HRV and IHNV (ChAb) were diluted $10^{-1}$ to $10^{-9}$ in BSS and $0.05 \mathrm{ml}$ of each dilution was inoculated into 4 wells of each cell line and the virus titers determined. The cell lines mentioned were also tested for their ability to support HRV growth. Cells were seeded in 25 $\mathrm{cm}^{2}$ flasks (Falcon) at a concentration of $1.0 \times 10^{6}$ flask $^{-1}$ in MEM with $10 \%$ FBS (MEM-10) and incubated for $3 \mathrm{~d}$. The cultures were then inoculated with HRV at a multiplicity of infection (MOI) of 0.1 , and 0.1 $\mathrm{ml}$ of culture medium was removed from each flask at Day 1, 3, 7, and 10, and the virus titer determined.

The optimum temperature for virus replication was determined using RTG-2 and EPC cells. Monolayer cultures of these cell lines were prepared in $25 \mathrm{~cm}^{2}$ flasks and infected with virus (HRV, IHNV, IPNV) at $\mathrm{MOI}=1$. After $2 \mathrm{~h}$ adsorption, cells were washed with BSS and then MEM-10 was added. The cultures were incubated at $5,10,15,20$, and $25^{\circ} \mathrm{C}$. At $1,4,8$, and $11 \mathrm{~d}$ post-infection, the titer in each flask was determined.

Stability of HRV in seawater. The stability of HRV in seawater was compared with its stability in cell culture medium. One $\mathrm{ml}$ of harvested virus was added to 9 volumes of autoclaved seawater or to $9 \mathrm{ml}$ of MEM-10. Both mixtures were held at $15^{\circ} \mathrm{C}$ and the virus titers were determined after 2, 5, 7, 10, 20, 30, 60, 96 and $152 \mathrm{~d}$.

Electron microscopy. Ultrathin sections of RTG-2 cells infected with HRV were prepared for examination by electron microscopy. Monolayer cell cultures were infected with HRV (MOI $=0.1$ ). After $24 \mathrm{~h}$ incubation at $15{ }^{\circ} \mathrm{C}$, cells were scraped from the flasks and fixed with $3 \%$ glutaraldehyde in $0.1 \mathrm{M}$ sodium cacodylate buffer, $\mathrm{pH} 7.4$ for $1 \mathrm{~h}$. Cells were washed with $0.1 \mathrm{M}$ sodium cacodylate buffer by centrifugation $(167 \times \mathrm{g}$ for $10 \mathrm{~min})$ and then post-fixed with $1 \% \mathrm{OsO}_{4}$ in $0.2 \mathrm{M}$ sodium cacodylate buffer for $30 \mathrm{~min}$. Pelleted cells were embedded in epoxy resin, sectioned, and stained with $2 \%$ uranyl acetate. The size of the virus particles was measured by comparison with polystyrene latex beads measuring $0.23 \mu \mathrm{m}$ in diameter (Oken Shoji Co., Tokyo).

Virus purification and antiserum preparation. Concentration of HRV-8401H was achieved by polyethylene glycol precipitation followed by centrifugation at $100000 \times \mathrm{g}$ for $1 \mathrm{~h}$ through $0.25 \%$ sucrose percol (Pharmacia Fine Chemicals). The virus band was removed and washed by centrifugation (100000 $\times \mathrm{g}$ for $1 \mathrm{~h}$ ) in phosphate buffered saline (PBS; $\mathrm{pH} 7$.2). The pelleted virus was then resuspended in TNE buffer $(0.2$ $M$ tris, $\left.0.15 \mathrm{M} \mathrm{NaCl}, 0.001 \mathrm{M} \mathrm{Na}_{2} E D T A, p H ~ 7.2\right)$ and dialyzed overnight against TNE buffer.

A New Zealand white rabbit was injected intravenously with purified virus both intramuscularly and subcutaneously with an emulsion of purified virus and Freund's incomplete adjuvant (1:1). The intramuscular and subcutaneous injections were carried out on Day 30,50 and 60 after primary inoculation. The rabbit was bled $10 \mathrm{~d}$ after the last injection. Serum was collected, sterilized by membrane filtration, inactivated at $56{ }^{\circ} \mathrm{C}$ for $30 \mathrm{~min}$ and stored at $-80^{\circ} \mathrm{C}$ until used.

Pathogenicity of $H R V$. The pathogenicity of the virus was tested in specific-pathogen-free chum salmon, masu salmon, coho salmon, rainbow trout and ayu. Rainbow trout $(8 \mathrm{~g})$, and masu salmon (6 g) were

Table 1. Biochemical and biophysical characterization of HRV

\begin{tabular}{|c|c|c|}
\hline \multirow[t]{2}{*}{ Characteristics } & \multicolumn{2}{|c|}{$\log \mathrm{TCID}_{50} \mathrm{ml}^{-1}$} \\
\hline & HRV $8401 \mathrm{H}$ & HRV A-8401H \\
\hline Control & 6.05 & 6.05 \\
\hline Ether treatment, $5^{\circ} \mathrm{C}, 18 \mathrm{~h}$ & $<1.80$ & $<1.80$ \\
\hline $\mathrm{pH} 3.0,3 \mathrm{~h}$ & 4.05 & 4.30 \\
\hline $50^{\circ} \mathrm{C}, 2 \mathrm{~min}$ & $<0.80$ & $<0.80$ \\
\hline $60^{\circ} \mathrm{C}, 1 \mathrm{~min}$ & $<0.80$ & $<0.80$ \\
\hline IUdR, $50 \mu \mathrm{g} \mathrm{ml}^{-1}$. & 6.05 & 6.30 \\
\hline Hemagglutination of human $O$ type erythrocytes * & Negative & Negative \\
\hline See text & & \\
\hline
\end{tabular}


injected intramuscularly with $0.1 \mathrm{ml}$ of MEM containing $10^{4.0} \mathrm{TCID}_{50} \mathrm{ml}^{-1}$ of virus. Groups of 10 fish each were injected with virus. Two groups received only MEM. All were held in $20 \mathrm{l}$ aquaria at 12 to $13^{\circ} \mathrm{C}$ for 21 $\mathrm{d}$ and observed daily for mortality. Fifty chum and coho salmon, 30 masu salmon and 15 ayu, weighing approximately $0.2,0.5,0.2$ and $0.5 \mathrm{~g}$, respectively, were infected by the immersion method using $10^{3.0} \mathrm{TCID}_{50}$ $\mathrm{ml}^{-1}$. Fish were exposed to the virus at $10^{\circ} \mathrm{C}$ for $60 \mathrm{~min}$ and then held for $21 \mathrm{~d}$ in $3 \mathrm{l}$ aquaria at 12 to $14^{\circ} \mathrm{C}$ (or at 16 to $17{ }^{\circ} \mathrm{C}$ in the case of the ayu). After $21 \mathrm{~d}$ of observation, samples of 5 fish from each challenged group were assayed for virus. Samples consisted of fish that had died during the observation period and fish that had survived. The fish were homogenized in BSS $(1: 10 \mathrm{w} / \mathrm{v})$ using a stomacher. The homogenates were filtered through a $0.45 \mu \mathrm{m}$ pore diameter filter and the virus titers determined.

\section{RESULTS}

\section{Biochemical and biophysical characterization}

Biochemical and biophysical characteristics of the HRV-8401H and HRV-A-8401H isolates are summarized in Table 1. Ether treatment markedly reduced infectivity of the viruses. The BSS-treated control had a titer of $10^{6.05} \mathrm{TCID}_{50} \mathrm{ml}^{-1}$ while the ether-treated suspension gave a titer less than $10^{1.8} \mathrm{TCID}_{50} \mathrm{ml}^{-1}$. This sensitivity to ether is evidence that the virus has an essential lipid-containing envelope.

The deoxyuridine analogue IUdR was not effective in blocking viral replication. Control cultures and IUdR treated cultures had similar titers $\left(10^{6.05} \mathrm{TCID}_{50}\right.$ $\mathrm{ml}^{-1}$ ). The lack of inhibition by halogenated pyrimidines is evidence that the virus possesses an RNA genome.

Both isolates were inactivated by exposure to $\mathrm{pH} 3.0$. No hemagglutination by HRV was observed with human $O$ type erythrocytes.

\section{Electron microscopy}

Virus particles in HRV-infected RTG-2 cells were bullet-shaped (Fig. 1). Measurements on 30 particles revealed them to be between 180 and $200 \mathrm{~nm}$ long and $80 \mathrm{~nm}$ in diameter. These morphological and biophysical features are characteristic of viruses of the Rhabdoviridae.

\section{Serological characterization}

The 5 isolates of HRV used were obtained from 2 host species at 3 different locations over a 2 yr period. All were neutralized with anti-HRV $8401 \mathrm{H}$ rabbit serum. No neutralization of $\mathrm{HRV}$ infectivity by antisera against IHNV, IPNV, OMV, VHSV, SVCV, PFRV, EVA or EVX was observed. The infectivity of each control virus used was reduced over 100 -fold by the homologous antiserum.

Cross-neutralization tests indicated that HRV was clearly distinguishable from the 5 reference rhabdoviruses (Table 2). The HRV was neutralized with homologous antiserum at a titer of 160 but was not neutralized with the heterologous antisera tested. Anti-IHNV, SVCV, EVA and EVX rabbit sera were also highly specific. Cross reactions were not observed except between EVA and EVX.

Table 2. Cross-neutralization tests with HRV, IHNV, VHSV, SVCV, EVA, EVX and PFRV

\begin{tabular}{|c|c|c|c|c|c|c|c|c|c|c|c|}
\hline \multirow[t]{3}{*}{ Virus } & \multirow{3}{*}{$\begin{array}{l}\text { Virus titer } \\
\text { Log } \\
\text { TCID }_{50} \\
\text { well }^{-1}\end{array}$} & \multicolumn{10}{|c|}{ Anti-sera $\left(\mathrm{ND}_{50}\right)^{1}$} \\
\hline & & \multirow{2}{*}{$\begin{array}{l}\text { HRV } \\
8401 \mathrm{H}\end{array}$} & \multicolumn{2}{|c|}{ IHNV } & \multicolumn{2}{|c|}{ VHSV } & \multicolumn{2}{|c|}{ SVCV } & \multirow{2}{*}{$\begin{array}{c}\text { PFRV } \\
\mathrm{K}\end{array}$} & \multirow{2}{*}{$\begin{array}{c}\text { EVA } \\
\mathrm{H}\end{array}$} & \multirow{2}{*}{$\begin{array}{c}\text { EVX } \\
H\end{array}$} \\
\hline & & & $\mathrm{HV}-1^{2}$ & $\mathrm{H}^{3}$ & $\mathrm{~K}^{4}$ & $A^{5}$ & $\mathrm{H}$ & $\mathrm{K}$ & & & \\
\hline HRV $8401 \mathrm{H}$ & 1.75 & 160 & $<17$ & $<42$ & $<42$ & $<42$ & $<42$ & $<42$ & $<17$ & $<42$ & $<42$ \\
\hline IHNV HV-1 & 2.00 & $<17$ & 90 & ND & ND & ND & ND & ND & ND & ND & ND \\
\hline IHNV H & 1.75 & $<17$ & ND & 141 & $<42$ & $<42$ & $<42$ & $<42$ & $<17$ & $<42$ & $<42$ \\
\hline SVCVH & 2.00 & $<17$ & ND & $<42$ & $<42$ & $<42$ & 141 & ND & $<17$ & $<42$ & $<42$ \\
\hline EVA $\mathrm{H}$ & 1.55 & $<17$ & ND & $<42$ & $<42$ & ND & $<42$ & $<42$ & ND & $\geqq 281$ & $\geqq 281$ \\
\hline PFRV K & 2.25 & $<17$ & ND & $<42$ & ND & $\mathrm{ND}$ & ND & ND & $\geqq 112$ & ND & ND \\
\hline $\begin{array}{l}{ }^{1} \mathrm{ND}_{50}=50 \% \\
{ }^{2} \text { Provided by } \\
{ }^{3} \text { Provided by } \\
{ }^{4} \text { Provided by } \\
{ }^{5} \text { Provided by } \\
\text { ND: not deter }\end{array}$ & $\begin{array}{l}\text { neutralizatio } \\
\text { Ministry of A } \\
\text { Or. B. J. Hill } \\
\text { Dr P. de Kin } \\
\text { Dr. W. Ahne } \\
\text { nined }\end{array}$ & $\begin{array}{l}\text { on titers } \\
\text { Agricultur } \\
\text { Akelin; an }\end{array}$ & $\begin{array}{l}\text { and Fis } \\
\text { iserum a }\end{array}$ & $\begin{array}{l}\text { ries } \\
\text { inst V }\end{array}$ & V was & yyvalen & & & & & \\
\hline
\end{tabular}




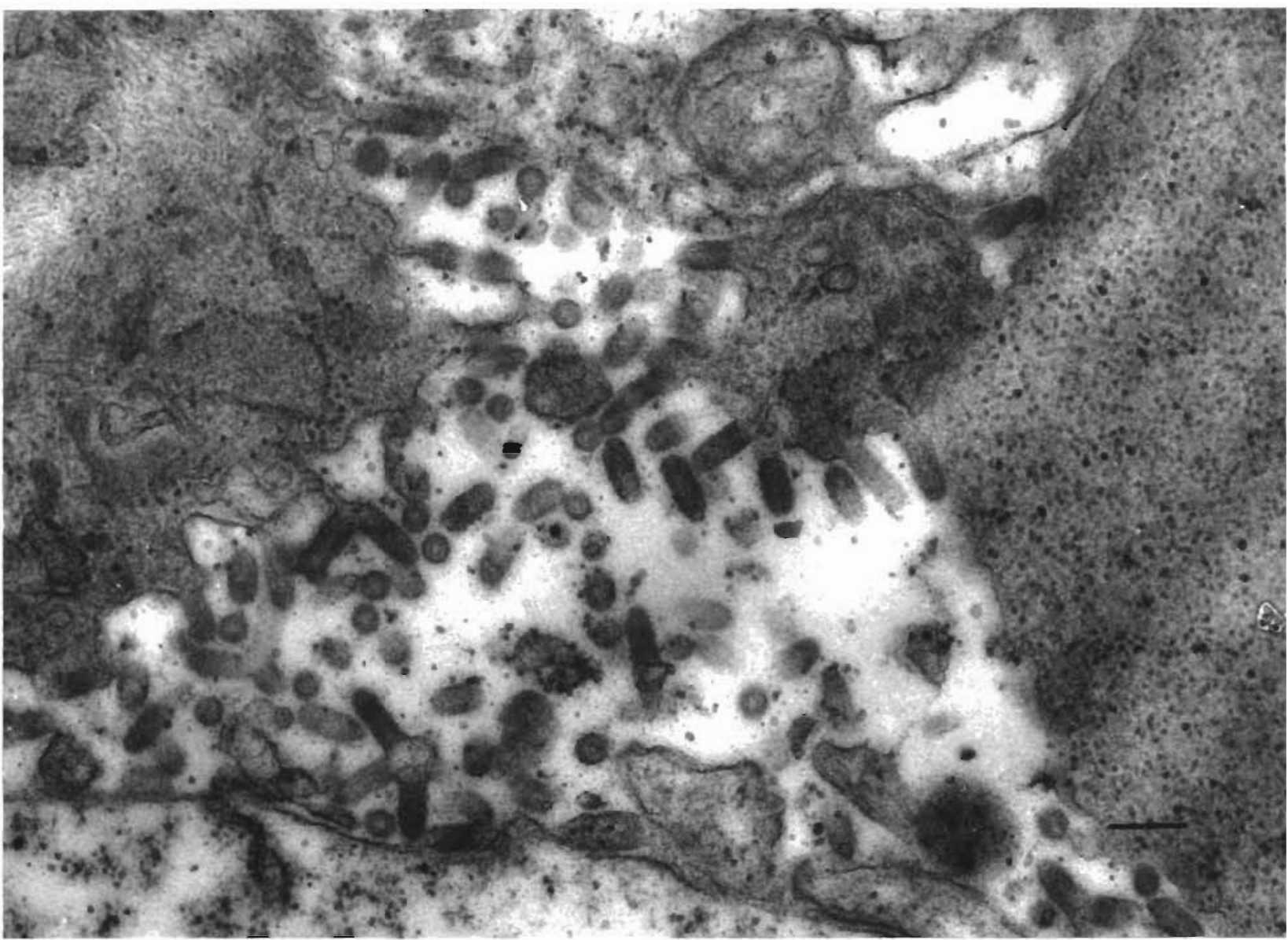

Fig. 1. Electron micrograph of an ultrathin section showing large numbers of bullet-shaped virus particles in rainbow trout gonad (RTG-2) cells infected with HRV. Stained with $2 \%$ uranyl acetate $(\mathrm{Bar}=200 \mathrm{~nm})$

\section{Cell line susceptibility and virus replication}

The HRV was originally isolated using RTG-2 cells. Of the 12 other fish cell lines also evaluated for HRV susceptibility, the EPC, FHM, BF-2, YNK, STE-137, BB, EK-1, CCO, and HF-1 lines were susceptible to HRV infection. The EPC and FHM cell lines showed the greatest sensitivity, while no CPE developed in $\mathrm{CHH}-$ 1, CHSE-214 and KO-6 cells (Table 3 ). The last 3 cell lines were susceptible to IHNV, but the HF-1, BB, EK-1 and $\mathrm{CCO}$ cells were not.

As judged by virus yield (Fig. 2), the FHM and RTG2 cells were the most efficient at replicating HRV. An incubation time of 3 to $5 \mathrm{~d}$ was required to observe CPE in EPC, HF-1, STE-137, and BF-2 cells; and the virus yields were $10^{8.80} \mathrm{TCID}_{50} \mathrm{ml}^{-1}$ or greater. No CPE developed in CHSE-214, CHH-1, or KO-6 cells even after $10 \mathrm{~d}$ incubation at $15^{\circ} \mathrm{C}$.

The temperature range for viral replication was determined to be 5 to $20^{\circ} \mathrm{C}$; no replication occurred at
Table 3. Comparison of cell line susceptibility to HRV and IHNV infection

\begin{tabular}{|c|c|c|c|c|}
\hline \multirow{2}{*}{ Cell lines } & \multicolumn{2}{|c|}{ HRV $-8401 \mathrm{H}$} & \multicolumn{2}{|c|}{ IHNV ChAb } \\
\hline & $\mathrm{CPE}^{1}$ & Titer $^{2}$ & CPE & Titer \\
\hline RTG-2 & + & 6.30 & + & 4.30 \\
\hline EPC & + & 7.30 & + & 6.30 \\
\hline FHM & + & 6.80 & + & 5.80 \\
\hline $\mathrm{BF}-2$ & + & 5.55 & + & 4.55 \\
\hline YNK & + & 6.30 & + & 4.55 \\
\hline STE-137 & + & 5.05 & + & 4.80 \\
\hline CHSE-214 & - & $<2.80$ & + & 5.55 \\
\hline $\mathrm{CHH}-1$ & \pm & $\leqq 3.05$ & + & 6.30 \\
\hline $\mathrm{KO}-6$ & - & $<2.80$ & + & 4.80 \\
\hline $\mathrm{HF}-1$ & + & 5.80 & - & $<2.80$ \\
\hline $\mathrm{BB}$ & + & 5.30 & - & $<2.80$ \\
\hline EK-1 & + & 3.80 & - & $<2.80$ \\
\hline $\mathrm{CCO}$ & + & 4.55 & - & $<2.80$ \\
\hline $\begin{array}{l}{ }^{1} \text { Cytopathi } \\
{ }^{2} \text { Log TCID }\end{array}$ & ${ }^{1}$ Cytopathic effects & & & \\
\hline
\end{tabular}




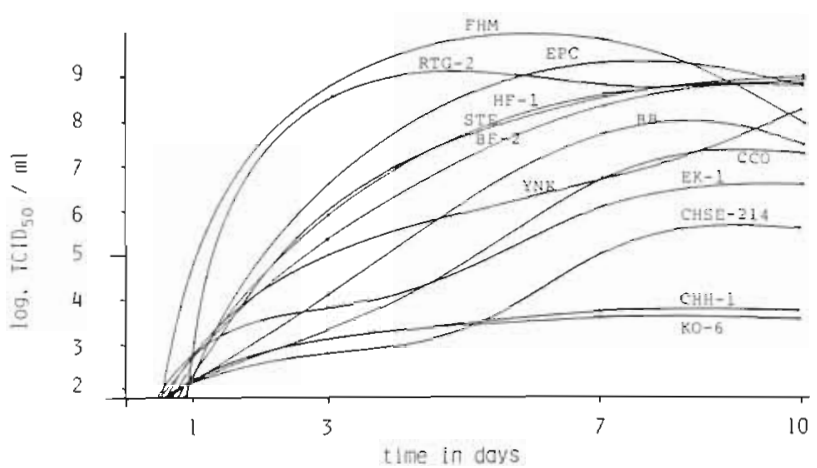

Fig. 2. Replication of HRV in selected fish cell lines incubated at $15^{\circ} \mathrm{C}, \mathrm{MOI}=0.1$

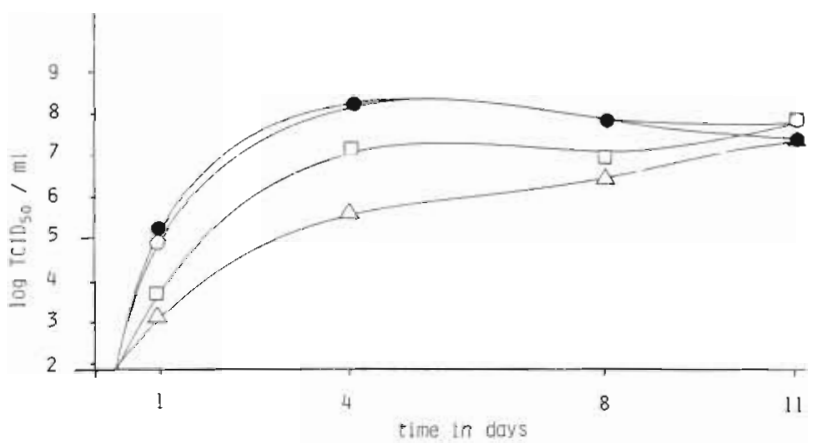

Fig. 3. Effect of temperature on replication of HRV in RTG-2



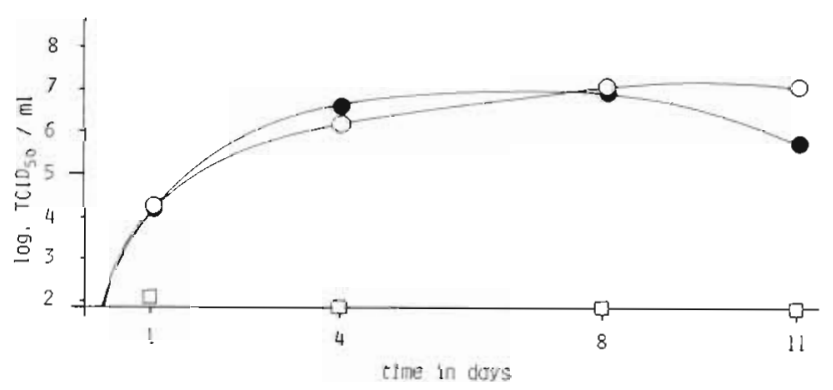

Fig. 4. Effect of temperature on replication of $\mathrm{HRV}$ in $\mathrm{EPC}$ cells. (O) $15^{\circ} \mathrm{C}$ (•) $20^{\circ} \mathrm{C} ;(\square) 25^{\circ} \mathrm{C}$

$25^{\circ} \mathrm{C}$ (Fig. $3 \& 4$ ). The RTG-2 cell line was used for those experiments performed at 5 to $20^{\circ} \mathrm{C}$ and the EPC cells, which tolerate higher temperatures, were used for tests at 15 to $25^{\circ} \mathrm{C}$. The extent of CPE correlated with the virus titer produced over the range of 5 to 20 ${ }^{\circ} \mathrm{C}$. At $10^{\circ} \mathrm{C}$, viral replication was slower and CPE less extensive than at 15 or $20^{\circ} \mathrm{C}$.

\section{Stability of HRV in seawater}

Virus was suspended in seawater or MEM at an initial concentration of $10^{6.80} \operatorname{TCID}_{50} \mathrm{ml}^{-1}$. The loss of infectivity of HRV in seawater appeared to follow firstorder kinetics for the first $5 \mathrm{~d}$ but at least $10^{4.20} \mathrm{TCID}_{50}$ $\mathrm{ml}^{-1}$ remained after $96 \mathrm{~d}$. Stability was slightly less in the seawater than in MEM.

\section{Pathogenicity}

Table 4 gives the results of the pathogenicity tests. Of the 2 species of salmonids challenged with HRV by injection, only 1 (rainbow trout) proved susceptible. In addition, none of the 3 species of salmonids and ayu challenged with HRV by the immersion method developed signs of disease even though 1 of them (the ayu) was known to be suspectible to the virus under hatchery conditions.

Virus isolations were carried out on 5 dead or surviving fish from each virus-challenged and control group. Virus was recovered from 5 individual rainbow trout (all mortalities); from 1 of 2 dead masu salmon fry and from 1 of 3 surviving masu salmon fry; and from 3 of 5 surviving coho salmon fry (Table 5). Signs of disease were only observed in rainbow trout. All the isolates were neutralized by anti-HRV serum.

Virus titers in tissues of infected rainbow trout were determined for kidney and spleen pools, liver and pancreas pools, heart, intestine, swimbladder and muscle. The virus was recovered from all tissues examined. Kidney and spleen pools had the highest titers (i.e. $10^{605}$ to $10^{6.90} \mathrm{TCID}_{50} \mathrm{ml}^{-1}$, Table 6).

\section{DISCUSSION}

The virus described here, provisionally termed hirame rhabdovirus (HRV) was isolated from cultured hirame and seawater-cultured ayu fry. The virus appears to be a new pathogen of marine fish. No evidence of a similar agent is noted among recent listings of fish viruses by Pilcher \& Fryer (1980), Wolf \& Mann (1980), Agius (1982), Johnson (1984) or Wolf (1984).

The HRV replicated in several fish cell lines at 5 to $20^{\circ} \mathrm{C}$. It was sensitive to $\mathrm{pH} 3$, diethyl ether, and heat $\left(50^{\circ} \mathrm{C}\right.$ for $\left.2 \mathrm{~min}\right)$, but replication was not inhibited by IUdR. The virion was bullet-shaped and measured 80 $\mathrm{nm} \times 180$ to $200 \mathrm{~nm}$. These morphological and biophysical features are characteristic of viruses belonging to the family Rhabdoviridae. Several other rhabdoviruses, including IHNV, VHSV, SVCV, PFRV, EVA and EVX are well-known fish pathogens. Another virus, swimbladder inflammation (SBI) virus, proved to be morphologically and serologically identical to SVCV (Bachmann \& Ahne 1973, 1974). The HRV was not neutralized with the antisera against IHNV, VHSV, 
Table 4. Comparison of mortality in rainbow trout, masu salmon, coho salmon, chum salmon and ayu artificially infected with HRV

\begin{tabular}{|c|c|c|c|c|c|c|c|c|c|}
\hline \multirow[t]{4}{*}{ Fish species } & \multirow{4}{*}{$\begin{array}{l}\text { Method } \\
\text { of } \\
\text { infection }\end{array}$} & \multirow[t]{4}{*}{ Experiment } & \multicolumn{6}{|c|}{ Number of fish } & \multirow{4}{*}{$\begin{array}{l}\text { Cumulative } \\
\text { mortality } \%\end{array}$} \\
\hline & & & \multirow[t]{3}{*}{ Employed } & \multicolumn{5}{|c|}{ Died } & \\
\hline & & & & \multicolumn{5}{|c|}{ Days after exposure } & \\
\hline & & & & 3 & 6 & 9 & 12 & 21 & \\
\hline \multirow{2}{*}{$\begin{array}{l}\text { Rainbow trout } \\
\text { (B.W. } 3.0 \mathrm{~g})\end{array}$} & $\mathrm{IP}^{\prime}$ & Test & 10 & 0 & 1 & 2 & 3 & 0 & 60 \\
\hline & & Control & 10 & 0 & 1 & 0 & 0 & 0 & 10 \\
\hline \multirow{2}{*}{$\begin{array}{c}\text { Masu salmon } \\
\text { (B.W. } 6.0 \mathrm{~g})\end{array}$} & IP & Test & 10 & 0 & 0 & 0 & 0 & 0 & 0 \\
\hline & & Control & 10 & 0 & 0 & 0 & 0 & 1 & 10 \\
\hline \multirow{2}{*}{$\begin{array}{r}\text { Coho salmon } \\
\text { (B.W. } 0.5 \mathrm{~g})\end{array}$} & $\mathrm{IS}^{2}$ & Test & 50 & 0 & 0 & 0 & 0 & 0 & 0 \\
\hline & & Control & 50 & 0 & 0 & 0 & 0 & 0 & 0 \\
\hline \multirow{2}{*}{$\begin{array}{c}\text { Chum salmon } \\
\text { (B.W. } 0.2 \mathrm{~g})\end{array}$} & IS & Test & 50 & 1 & 3 & 1 & 0 & 0 & 10 \\
\hline & & Control & 50 & 1 & 1 & 0 & 0 & 1 & 6 \\
\hline \multirow{2}{*}{$\begin{array}{l}\text { Masu salmon } \\
\text { (B.W. } 0.2 \mathrm{~g} \text { ) }\end{array}$} & IS & Test & 30 & 2 & 0 & 0 & 0 & 0 & 7 \\
\hline & & Control & 30 & 0 & 0 & 0 & 0 & 0 & 0 \\
\hline \multirow{2}{*}{$\begin{array}{l}\text { Ayu } \\
\text { (B.W. } 0.5 \mathrm{~g})\end{array}$} & IS & Test & 15 & 0 & 0 & 0 & 0 & 0 & 0 \\
\hline & & Control & 15 & 0 & 0 & 0 & 0 & 0 & 0 \\
\hline \multicolumn{10}{|c|}{1 Intraperitoneal injection: challenge dose, $1.0 \times 10^{4} \mathrm{TClD}_{50} \mathrm{fish}^{-1}$} \\
\hline
\end{tabular}

Table 5. Virus isolation from rainbow trout, masu salmon, coho salmon, chum salmon and ayu exposed to HRV

\begin{tabular}{|c|c|c|c|c|c|}
\hline \multirow[t]{2}{*}{ Fish species } & \multirow[t]{2}{*}{ Method of infection } & \multirow[t]{2}{*}{ Experiment } & \multicolumn{2}{|c|}{ Virus } & \multirow{2}{*}{$\begin{array}{c}\text { Neutralization } \\
\text { test }^{4}\end{array}$} \\
\hline & & & Isolation & Titer $^{3}$ & \\
\hline Rainbow trout & $\mathrm{IP}^{1}$ & $\begin{array}{l}\text { Test } \\
\text { Control }\end{array}$ & $\begin{array}{l}5 / 5 \\
0 / 5\end{array}$ & $\begin{array}{r}\geqq 3.80 \\
\text { ND }\end{array}$ & Yes \\
\hline Masu salmon & IP & $\begin{array}{l}\text { Test } \\
\text { Control }\end{array}$ & $\begin{array}{l}1 / 5 \\
0 / 5\end{array}$ & $\begin{aligned} \geqq & 3.80 \\
& N D\end{aligned}$ & Yes \\
\hline Coho salmon & $\mathrm{IS}^{2}$ & $\begin{array}{l}\text { Test } \\
\text { Control }\end{array}$ & $\begin{array}{l}3 / 5 \\
0 / 5\end{array}$ & $\begin{aligned} \geqq & 3.80 \\
& N D\end{aligned}$ & Yes \\
\hline Chum salmon & IS & $\begin{array}{l}\text { Test } \\
\text { Control }\end{array}$ & $\begin{array}{l}0 / 5 \\
0 / 5\end{array}$ & $\begin{array}{l}\text { ND } \\
\text { ND }\end{array}$ & \\
\hline Masu salmon & IS & $\begin{array}{l}\text { Test } \\
\text { Control }\end{array}$ & $\begin{array}{l}2 / 5 \\
0 / 5\end{array}$ & $\begin{array}{r}\geqq 3.80 \\
\text { ND }\end{array}$ & Yes \\
\hline Ayu & IS & $\begin{array}{l}\text { Test } \\
\text { Control }\end{array}$ & $\begin{array}{l}0 / 5 \\
0 / 5\end{array}$ & $\begin{array}{l}\text { ND } \\
\text { ND }\end{array}$ & \\
\hline \multicolumn{6}{|c|}{$\begin{array}{l}{ }^{1} \text { Intraperitoneal injection } \\
{ }^{2} \text { Immersion method } \\
{ }^{3} \text { Log TCID }_{50} \mathrm{ml}^{-1} \\
{ }^{4} \text { With anti-HRV } 8401 \mathrm{H} \text { rabbit serum }(1: 100) \text { vs } 100 \mathrm{TCID}_{50} \text { well }^{-1} \\
\text { ND: not determined }\end{array}$} \\
\hline
\end{tabular}

SVCV, PFRV, EVA or EVX. Cross-neutralization tests indicated that HRV was clearly distinguishable from these reference rhabdoviruses.

The HRV showed IHNV-like CPE, progressing eventually to cytolysis, in cultured FHM, EPC, BF-2, RTG-2, STE-137, HF-1, BB, YNK, CCO, and EK-1 cells. However, the CHSE-214, CHH- 1 and $\mathrm{KO}-6$ cell lines, which were all derived from salmonid fish and have a similar epitheloid morphology, were refractory to HRV. This pattern of cell susceptibility was clearly different from that of IHNV and VHSV. Although little information is available, the HRV also appears to be readily distinguishable, on the basis of the susceptibility of various cell lines, from the rhabdovirus of cod ulcus syndrome (Jensen et al. 1979) and from a recently described crab rhabdovirus (Johnson 1984). 
Table 6. Virus titers in kidney, spleen, liver, pancreas and swim bladder of HRV-infected rainbow trout

\begin{tabular}{|clc|}
\hline Specimen & \multicolumn{1}{c}{ Organ } & $\begin{array}{c}\text { Titer } \\
\text { Log } \text { TCID }_{50} \text { g }^{-1}\end{array}$ \\
\hline I & Kidney + spleen & 6.05 \\
& Liver + pancreas & 4.30 \\
& Heart & 3.55 \\
& Intestine & 5.80 \\
II & Kidney + spleen & 6.80 \\
& Liver + pancreas & 4.05 \\
& Swimbladder & 5.80 \\
& Muscle & 4.80 \\
RTG-2 cells used for assay & \\
\hline
\end{tabular}

Although most rhabdoviruses isolated from non-salmonid fishes (for example SVCV, PFRV, EVA and EVX, the virus isolated from grass carp [Alne 1975] and the virus from a North American cichlid [Malsberger \& Lautenslager 1980]) replicate at $25^{\circ} \mathrm{C}$ or above, HRV did not replicate at $25^{\circ} \mathrm{C}$. A comparison between HRV and Rhabdovirus salmonis (Osadchaya \& Nakonechnaya 1981) could not be made because of the limited information available.

The pathogenicity of HRV for hirame was observed following intraperitoneal injection into 100 to $250 \mathrm{~g}$ fish (Gorie et al. 1986). The cumulative mortality was $20 \%$, but mortality was not observed at $16{ }^{\circ} \mathrm{C}$ or above. The mortalities of hirame in natural outbreaks in Hyogo were $25 \%$ (1984) and $7.2 \%$ (1985). For Kagawa Prefecture the mortality was $3.3 \%$ but for Hokkaido it was greater than $90 \%$. The size of fish affected ranged from 100 to $700 \mathrm{~g}$. The high mortality rate among naturally infected hirame observed in Hokkaido may have been due to the low rearing temperatures in the winter $\left(2\right.$ to $\left.5^{\circ} \mathrm{C}\right)$. We are now investigating the ultrastructure of tissues from naturally $\mathrm{HRV}$-infected hirame and will publish the results in the near future.

Experimentally, HRV was lethal for rainbow trout, the cumulative mortality being $60 \%$. The signs of HRV infection in rainbow trout were similar to those caused by the salmonid virus, VHSV, because hemorrhaging in muscles was commonly seen. Interestingly, Castric \& de Kinkelin (1984) have reported that VHSV is also pathogenic for sea bass and turbot. The gross signs and histopathological data reported for these 2 marine species were similar to those observed in HRVinfected hirame.

Chum, coho and masu salmon fry and ayu fry experienced low or no mortalities when exposed to HRV by an immersion method. It may therefore be that these species are resistant to the virus, or that, in the case of the ayu, the experimental temperatures were too high to favor the virus. However, HRV was isolated from some of the dead and surviving fish exposed to virus. If the experiment had been extended, higher mortalities might therefore have been observed.

From the evidence obtained thus far, HRV is a new pathogenic virus of fish. This virus is now considered to be an important pathogen of cultured hirame and salmonids in Japan. We propose the name Rhabdovirus olivaceus n.sp., for this new rhabdovirus because it was first isolated from diseased hirame (Japanese flounder) Paralichthys olivaceus.

Acknowledgements. The authors express their sincere gratitude to Dr. B. J. Hill, Fish Disease Laboratory, Ministry of Agriculture, Fisheries and Food, U. K.; Dr. P. de Kinkelin, Institute National de la Research Agronomique, France; Dr W. Ahne, Institut für Zoologie und Hydrobiologie, Universität München, F. R. Germany; and the staff of Hyogo, Kagawa and Okayama Prefectural Fisheries Experimental Stations for their assistance. We thank Drs. J. L. Fryer, J. Rohovec and J. R. Winton, Oregon State University, USA, for their critical reviews of the paper and their valuable suggestions.

\section{LITERATURE CITED}

Agius, C. (1982). Virus diseases of warm water fish. In: Roberts, R. T. (ed.) Microbial diseases of fish. Academic Press, New York

Ahne, W. (1975). A rhabdovirus isolated from grass carp (Ctenopharyngodon idella var.). Arch. Virol. 48: 181-185

Bachmann, P. A., Ahne, W. (1973). Isolation and characterization of agent causing swimbladder inflammation in carp. Nature, Lond. 244: 235-237

Bachmann, P. A., Ahne, W. (1974). Biological properties and identification of the agent causing swimbladder inflammation in carp. Arch. ges. Virusforschung 44: 261-269

Bowser, P. R., Plumb, J. A. (1980). Fish cell lines: establishment of a line from ovaries of channel catfish. In Vitro 16: 365-368

Castric, J., de Kinkelin, P. (1984). Experimental study of the susceptibility of two marine fish species, sea bass (Picentrarchus labrax) and turbot (Scophthalmus maximus), to viral haemorrhagic septicaemia. Aquaculture 46: 203-212

Chen, S. W., Ueno, Y., Kou, G. H. (1982). A cell line derived from Japanese eel (Anguilla japonica) kidney. Proc. Natl. Sci. Coun., ROC 6: 93-100

Gorie, S., Nakamoto, K., Katashima, K. (1985a). Diseases of cultured hirame (Japanese flounder, Paralichthys olivaceus) - I. Preliminary report on a disease of marine pen cultured hirame may be caused by viral infection. Bull. Hyogo Pref. Fish. Exp. Stn 23: 66-68

Gorie, S., Katashima, K., Tahata, K. (1985b). Disease of cultured ayu (Plecoglossus altivelis). Ann. Rep. Hyogo Pref. Fish. Exp. Stn, 297-300

Gorie, S., Katashima, K., Tahata, K. (1986). Disease of cultured hirame (Japanese flounder, Paralichthys olivaceus) - II. Pathogenicity of a virus isolated from cultured hirame Fish Pathol. 21: in press

Gravell, M., Malsburger, R. G. (1965). A permanent cell line from the fathead minnow (Pimephales promelas). Ann. N. Y Acad. Sci. 126: 555-565

Hsiung, G. D. (1982). Hemagglutination and the hemagglutination-inhibition test. In: Diagnostic virology. Yale University Press, New Haven and London, p. 276 
Jensen, N. I., Bloch, B., Larsen, J. L. (1979). The ulcus-syndrome in cod (Gadus morhua)-III. A preliminary virological report. Nordisk Veterinaermedicin 31: 436-442

Johnson, P. T. (1984). Viral diseases of marine invertebrates. Helgoländer Meeresunters. 37: 65-98

Lannan, C. N., Winton, J. R., Fryer, J. L. (1984). Fish cell lines Establishment and characterization of nine cell lines from salmonids. In Vitro 20:671-676

Malsberger, R. G., Lautenslager, G. (1980). Fish viruses: rhabdovirus isolated from a species of the family Cichlidae. Fish Health News 9: i-ii

Osadchaya, Ye. F., Nakonechnaya, M. G. (1981). Rhabdovirus salmonis, the cause of a new disease in rainbow trout, Salmo gairdneri. J. Ichthyol. 21: 113-121

Pilcher, K. S., Fryer, J. L. (1980). The viral diseases of fish: a review through 1978. In: Isenberg, H. D. (ed.) CRC critical reviews in microbiology, Vol 7, p. 287-363; Vol 8, p. 1-25.

Reed, L. J., Muench, H. (1938). A simple method of estimating fifty percent end points. Ann. J. Hygiene 27: 493-497
Tomasec, J., Fijan, N. (1971). Virusne bolestiriba (viral diseases of fish). Final report on research under a part of project $6 \mathrm{n} / 1966$, Zagreb

Watanabe, T., Kobayashi, N., Sato, Y., Ishizaki, Y. (1978). Continuous cell line derived from kidney of Yamame. Oncorhynchus masou. Bull. Jap. Soc. scient Fish. 44: 415-418

Wolf, K. (1984). Diseases of pisces; Diseases caused by microorganisms; Agents: Virales. In: Kinne, O. (ed.) Diseases of marine animals, Vol. IV, Part 1. Biologische Anstalt Helgoland, Hamburg, p. 17-47

Wolf, K., Mann, J. A. (1980). Poikilotherm vertebrate cell lines and viruses: A current listing for fishes. In Vitro 16: 168-179

Wolf, K., Quimby, M. C. (1962). Established eurythermic line of fish cells in vitro. Science 135: 1065-1066

Wolf, K., Quimby, M. C. (1966). Lymphocystis virus: Isolation and propagation in centrarchid fish cell lines. Science 151: $1004-1005$

Responsible Subject Editor: Dr. T. Evelyn; accepted for printing on July 4, 1986 